\title{
Job Satisfaction and Nursing Performance through Career Development
}

\author{
G. Nur Widya Putra*1, Tri Kurniati ${ }^{2}$, Abdul Aziz Alimul Hidayat ${ }^{3}$ \\ ${ }^{12}$ Faculty of Nursing, University of Muhammadiyah Jakarta, Jl. Cempaka Putih Tengah I/1 Jakarta \\ Pusat, Indonesia 10510 \\ ${ }^{3}$ Faculty of Nursing, University of Muhammadiyah Surabaya, Jl. Raya Sutorejo No. 59, Mulyorejo, \\ Surabaya, Indonesia 60113 \\ *Corresponding author: widyaputra90@gmail.com
}

\begin{abstract}
Background : Nursing performance becomes the essence in the success of nursing service at hospital, one way how to reach are enhancement of job satisfaction from nursing career development. Objectives: The research is to analyze know the influence of career development to job satisfaction and nursing performance in Buleleng hospital, Indonesia. Methods: This research method was correlation study with cross sectional approach. Population in this research is all nurses who exists in RSUD Buleleng District. Using a sample 178 peoples, with inclusion criteria was nurse's work minimum 1 year period. The sampling technique is purposive sampling. Results: The research were indicated career development has positive and significant effect on job satisfaction. It showed from the first hypothesis was $p$ value of $X$ (career development) $=0,000<0.05$ with $C R=$ 3,390. The second hypothesis informed $p$ value of $Y 1$ (job satisfaction) $=0,003<0.05$ with $C R=$ 2,998 which mean job satisfaction (Y1) has positive and significant effect to nursing performance. It represent career development indirectly has influence to nursing performance from job satisfaction. Conclusion: The good of career development has effect towards job satisfaction and indirectly enhancement to nursing performance.
\end{abstract}

Keywords: Career Development, Job Satisfaction, Nursing Performance, Hospital

\section{INTRODUCTION}

Hospital is an organization has a strategic function especially in the field of health, it required to perform quality medical duties and obligations $(\mathrm{MOH}, 2010)$. Operation of hospital function was determined by Human Resources (HR) (Robbins, 2012). (Health Ministry of Indonesian Republic, 2017) states that of the 1,149 employees in the District Hospital of Buleleng, as many as 313 people are nurses. The problem is still the low performance of nurses at the hospital due to nurse dissatisfaction. This is evident from the results of preliminary interviews on 10 nurses in Buleleng District General Hospital on March $9^{\text {th }}$ to March $12^{\text {th }} 2017$, were known that the job satisfaction of the salary of 7 people was feel less satisfied because looking at the side of work with income received less appropriately.

One of the efforts that can be done for it was career development nurse. According to Rivai and Sagala (2012), career development is the process of enhancing individual work ability achievement in order to get the desired career. Career level is a system to improve the performance and professionalism of nurses. Professional career of nurse's consists of 4 level. They are clinical nurses (PK), nurse managers (PM), nurse educators (PP), research nurse / research (PR) $(\mathrm{MOH}, 2010)$. Based on data from Nursing Division of RSUD Buleleng District, from 313 nurses in RSUD, 75\% was still in PK-I and PK-II. 


\section{METHOD}

This research method is correlation study with cross sectional approach. Population in this research is all nurses who exists in RSUD Buleleng District. Using a sample 178 peoples, with inclusion criteria was nurse's work minimum 1 year period. The sampling technique is purposive sampling. The exogenous variable is career development. Endogenous variables are job satisfaction and nursing performance. The data taken in this study comes from questionnaires and documents. Data analysis is Structural Equation Modeling (SEM) analysis, with AMOS software.

\section{RESULTS AND DISCUSSION}

Table 1 Respondent Characteristics (Gender, Age, Years of Service and Level of Education, n=178)

\begin{tabular}{|c|c|c|c|}
\hline No & Respondent Characteristics & $\mathbf{N}$ & Percentage \\
\hline 1 & $\begin{array}{cl}\text { Gender } & \\
\bullet & \text { Male } \\
\bullet & \text { Female }\end{array}$ & $\begin{array}{c}50 \\
128\end{array}$ & $\begin{array}{l}28,1 \% \\
71,9 \%\end{array}$ \\
\hline 2 & $\begin{aligned} \text { Age } & \\
\bullet & \leq 30 \text { Year } \\
\bullet & 31-40 \text { Year } \\
\bullet & \geq 41 \text { Year }\end{aligned}$ & $\begin{array}{l}71 \\
60 \\
47 \\
\end{array}$ & $\begin{array}{l}39,9 \% \\
33,7 \% \\
26,4 \% \\
\end{array}$ \\
\hline 3 & $\begin{array}{c}\text { Years of Service } \\
\cdot \quad \leq 10 \text { Years } \\
-\quad 11-20 \text { Years } \\
\bullet \quad \geq 21 \text { Years } \\
\end{array}$ & $\begin{array}{l}109 \\
38 \\
31 \\
\end{array}$ & $\begin{array}{l}61,2 \% \\
21,3 \% \\
17,4 \% \\
\end{array}$ \\
\hline 4 & $\begin{array}{l}\text { Level of Education } \\
\text { - Vocational High School of Nursing } \\
\text { - D3-Nursing } \\
\text { - D4-Nursing } \\
\text { - } \text { Bachelor of Nursing } \\
\text { Master }\end{array}$ & $\begin{array}{c}12 \\
98 \\
2 \\
62 \\
4\end{array}$ & $\begin{array}{c}6,7 \% \\
55,1 \% \\
1,1 \% \\
34,8 \% \\
2,2 \% \\
\end{array}$ \\
\hline
\end{tabular}

* The largest number of respondents are women, 128 people, in the age group of $\leq 30$ years, there was 71 people. Most of the respondents were in the group with Nursing D3 level with 98 students.

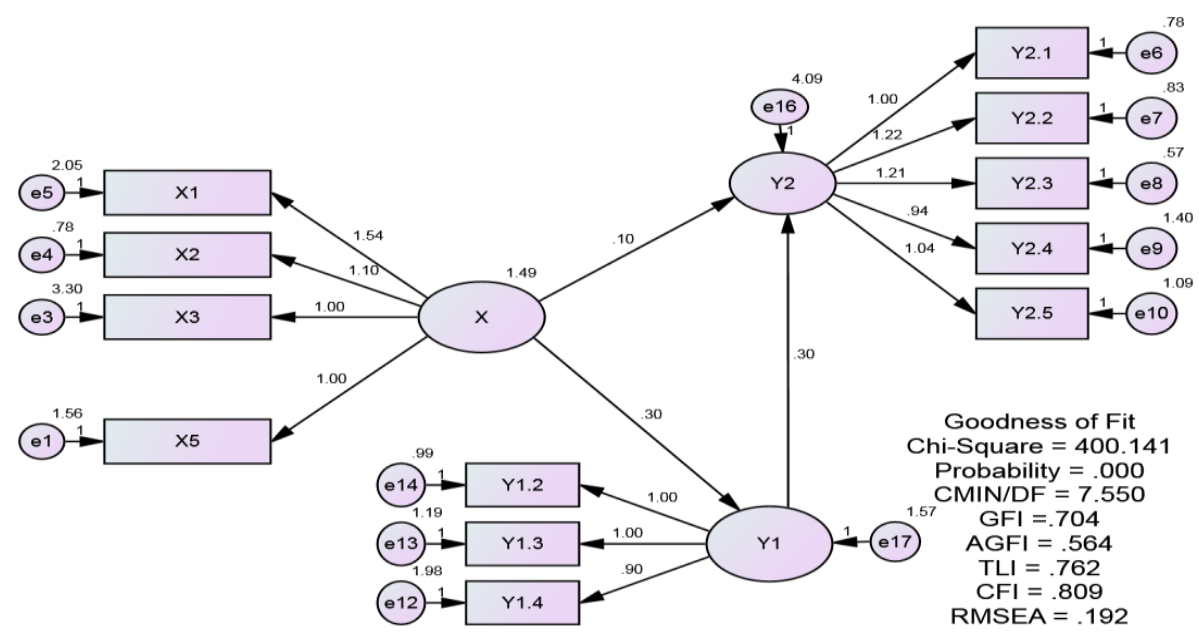

Figure 1 Confirmatory Factor Anaysis of Career Development, Job Satisfaction and Nursing Perfomance 
Table 2 CFA Process on Career Development Indicator, Job Satisfaction and Nursing Performance

\begin{tabular}{|c|c|c|c|c|c|c|c|}
\hline \multicolumn{3}{|c|}{ Regression Weights } & \multirow{2}{*}{$\begin{array}{r}\text { Estimate } \\
.024\end{array}$} & \multirow{2}{*}{$\frac{\text { S.E. }}{.035}$} & \multirow{2}{*}{$\begin{array}{l}\text { C.R. } \\
.692\end{array}$} & \multirow{2}{*}{$\begin{array}{c}\mathrm{P} \\
.489\end{array}$} & \multirow{2}{*}{$\frac{\text { Label }}{\text { par_15 }}$} \\
\hline Y1 & $<---$ & $\mathrm{X}$ & & & & & \\
\hline Y2 & $<---$ & $\mathrm{X}$ & .113 & .172 & .658 & .511 & par_13 \\
\hline Y2 & $<---$ & Y1 & 3.920 & 6.175 & .635 & .525 & par_14 \\
\hline $\mathrm{X} 5$ & $<---$ & $\mathrm{X}$ & 1.000 & & & & \\
\hline $\mathrm{X} 4$ & $<---$ & $\mathrm{X}$ & .906 & .144 & 6.271 & .000 & par_1 \\
\hline $\mathrm{X} 3$ & $<---$ & $X$ & 1.477 & .193 & 7.650 & .000 & par_2 \\
\hline $\mathrm{X} 2$ & $<---$ & $\mathrm{X}$ & 1.212 & .139 & 8.727 & .000 & par_3 \\
\hline $\mathrm{X} 1$ & $<---$ & $\mathrm{X}$ & 1.730 & .202 & 8.585 & .000 & par_4 \\
\hline Y2.1 & $<---$ & Y2 & 1.000 & & & & \\
\hline Y 2.2 & $<---$ & Y2 & 1.222 & .053 & 23.123 & .000 & par_5 \\
\hline Y2.3 & $<---$ & $\mathrm{Y} 2$ & 1.210 & .049 & 24.704 & .000 & par_6 \\
\hline Y2.4 & $<---$ & Y2 & .942 & .054 & 17.576 & .000 & par_7 \\
\hline Y2.5 & $<---$ & $\mathrm{Y} 2$ & 1.046 & .052 & 20.220 & .000 & par_8 \\
\hline Y1.5 & $<---$ & Y1 & 1.000 & & & & \\
\hline Y1.4 & $<---$ & Y1 & 16.113 & 23.007 & .700 & .484 & par_9 \\
\hline Y1.3 & $<---$ & Y1 & 20.740 & 29.568 & .701 & .483 & par_10 \\
\hline Y1.2 & $<---$ & Y1 & 16.298 & 23.247 & .701 & .483 & par_11 \\
\hline Y1.1 & $<--$ & Y1 & 11.312 & 16.170 & .700 & .484 & par 12 \\
\hline
\end{tabular}

Table 3 Indicator Residual Correlation Process till got Fit Model

\begin{tabular}{lcccc}
\hline \multicolumn{1}{c}{ Goodness-Of-Fit (GOF) } & Analysis Score & & Cut Off Value & Model's Evaluation \\
\hline Chi-square & $\begin{array}{c}\chi^{2}=185,069 \\
\mathrm{P}=0.000\end{array}$ & Probabilitas $\geq 0,05$ & Low \\
\hline TLI & 0,883 & TLI $>0.90$ & Approaching \\
\hline GFI & 0,858 & GFI $>0.90$ & Approaching \\
\hline AGFI & 0,753 & AGFI $>0.90$ & Low \\
\hline CFI & 0,923 & CFI $>0.90$ & Good \\
\hline RMSEA & 0,133 & RMSEA $\leq 0.08$ & Low \\
\hline
\end{tabular}


Table 4 Hypothesis Test Result

\begin{tabular}{|c|c|c|c|c|c|c|c|}
\hline \multicolumn{3}{|c|}{ Regression Weights } & \multirow{2}{*}{$\begin{array}{r}\text { Estimate } \\
.300\end{array}$} & \multirow{2}{*}{$\begin{array}{l}\text { S.E. } \\
.090\end{array}$} & \multirow{2}{*}{$\begin{array}{l}\text { C.R. } \\
3.312\end{array}$} & \multirow{2}{*}{$\begin{array}{c}\mathrm{P} \\
.000\end{array}$} & \multirow{2}{*}{$\begin{array}{l}\text { Label } \\
\text { par_18 }\end{array}$} \\
\hline Y1 & $<--$ & $\mathrm{X}$ & & & & & \\
\hline Y2 & $<---$ & Y1 & .415 & .138 & 2.998 & .003 & par_8 \\
\hline $\mathrm{X} 2$ & $<---$ & $\mathrm{X}$ & 1.011 & .092 & 10.952 & .000 & par_1 \\
\hline $\mathrm{X} 1$ & $<---$ & $\mathrm{X}$ & 1.423 & .133 & 10.661 & .000 & par_2 \\
\hline Y2.1 & $<---$ & $\mathrm{Y} 2$ & 1.000 & & & & \\
\hline $\mathrm{Y} 2.2$ & $<---$ & $\mathrm{Y} 2$ & .968 & .146 & 6.636 & .000 & par_3 \\
\hline Y2.3 & $<---$ & $\mathrm{Y} 2$ & .836 & .202 & 4.132 & .000 & par_4 \\
\hline Y2.4 & $<---$ & $\mathrm{Y} 2$ & .554 & .201 & 2.763 & .006 & par_5 \\
\hline Y2.5 & $<---$ & $\mathrm{Y} 2$ & .837 & .131 & 6.383 & .000 & par_6 \\
\hline Y1.4 & $<---$ & $\mathrm{Y} 1$ & .881 & .107 & 8.259 & .000 & par_7 \\
\hline Y1.3 & $<---$ & Y1 & 1.000 & & & & \\
\hline $\mathrm{X} 5$ & $<---$ & $\mathrm{X}$ & 1.000 & & & & \\
\hline $\mathrm{Y} 1.2$ & $<--$ & $\mathrm{Y} 1$ & 1.000 & & & & \\
\hline X3 & $<---$ & $X$ & 1.000 & & & & \\
\hline
\end{tabular}

In the table 4 showed that the $\mathrm{p}$ value of variable $\mathrm{X}$ (career development) $=0.000$ $<0.05$, where $\mathrm{p}$ value $<0.05$ with value of $\mathrm{CR}=3,390$ so $\mathrm{H} 0$ is rejected and $\mathrm{H} 1$ accepted. Which means career development $(\mathrm{X})$ have positive and significant effect to nurse's job satisfaction (Y1). In the table 5 showed that the $\mathrm{p}$ value of the variable $\mathrm{Y} 1=0.003<0.05$ with the value of $\mathrm{p}$ value $<0.05$ and also seen the value of $\mathrm{CR}=2,998$ so $\mathrm{H} 0$ rejected, which means variable Y1 (nurses's job satisfaction) have a positive and significant effect on variable Y2 (nurse's work performance)

This study proves that there was an influence of career development on nurse job satisfaction. It is seen on the result of hypothesis testing were done with $p$ value $=0,000$ $<0,05$ and value of $\mathrm{CR}=3,390$. Thus it can be said that there is a positive and significant influence between career developments on nurse job satisfaction. The results of this study supported by the statement presented by Siagian (2012) states that career development of employees need to consider five factors, one of which is the level of one's satisfaction, which is meant here is job satisfaction. These results are also in accordance with the statement put forward by Dubrin (2010) states that the purpose of career development is to show the welfare relationship of company employees, in this case in terms of income. Income / salary including one indicator of job satisfaction so it can be concluded that career development related to job satisfaction.

Based on the theory put forward by Patricia Banner (in Alligood, 2014) "From Novice to Expert" suggests that in nursing career development experience 5 levels, namely (1) novice, (2) advanced beginner, (3) competent, (4) proficient, and (5) expert. The first level (novice) a nurse is said to still gain knowledge in nursing school until finally entering the world of work. Stages of this novice is said that the nurse is in the career path PK-I. The 
higher the stages were achieved, the more of it will develop nursing career. This has an impact on higher job satisfaction. These conditions when associated with the theory of Hierarchy Maslow, it is said that every individual will feel satisfaction after basic needs are met and always trying to satisfy himself by meeting the needs of a higher level. Based on the description, the researcher believes that career development consisting of six indicators of job performance, exposure, organizational loyalty, mentor and sponsorship, opportunities for growth and management support have a positive and significant impact on job satisfaction

This study proves that there is influence of nurse's job satisfaction on nurse's performance. This can be seen from the hypothesis testing shows the value of $p=0.003$ $<0.05$, with the value of $\mathrm{CR}=2.998$ so that $\mathrm{H} 0$ is rejected. This means that there can be positive and significant influence between nurse's job satisfaction and nurse performance. The results of this study supported by the statement proposed by Nursalam (2015) that the performance of nurses is influenced by factors in the nurse, one of which is job satisfaction. This research is also supported by the theories proposed by Patricia Banner (in Alligood, 2014), "From Novice to Expert" suggests that in nursing career development experience 5 levels: (1) novice, (2) advanced beginner, (3) competent, (4) proficient, and (5) expert. From this theory it is also suggested that the higher the career path of a nurse, the job satisfaction increases, followed by the performance also increased too. Based on the description above, the researcher argues that nurse's job satisfaction consisting of five indicators, namely income, occupation, promotion, supervision and colleagues have a positive and significant influence on nurse performance.

\section{CONCLUSION}

The results of this study prove that career development has a positive and significant impact on nurse job satisfaction. Job satisfaction has a positive and significant effect on nurse performance. Career development has an indirect effect on nurse performance through job satisfaction.

\section{ACKNOWLEDGEMENT}

The authors would like to thank the nurses of Buleleng District Hospital for their participation in launching the research process. Thank you also the authors say to the University of Muhammadiyah Jakarta and the Director of RSUD Buleleng District that has given the opportunity to conduct the research process.

\section{REFERENCES}

Alligood., MR., (2014). Nursing Theorist and their work. Philadelphia: Elsevier

Dar, I. S., \& Ahsan-ul-haq, M. (2015). Factors Influencing Job Satisfaction Of Nurses In Public Hospitals. pp : 1761-1765.

Ministry of Helath. (2010). Peningkatan Manajemen Kinerja Klinik (PMKK) Perawat danBidan.Jakarta. Pusdiklat SDM Kesehatan Bekerjasama Dengan Direktorat Bina Pelayanan Keperawatan.

Mohajjel-aghdam, A., Hassankhani, H., Zamanzadeh, V., \& Khameneh, S. (2013). Knowledge and Performance about Nursing Ethic Codes from Nurses â $\epsilon^{T M}$ and Patients â€ ${ }^{T M}$ Perspective in Tabriz Teaching Hospitals, Iran. pp : 219-227.

Rivai, V.\& Sagala, E.J.(2012). Manajemen Sumber Daya Manusia Untuk Perusahaan Dari Teori dan Praktik. Jakarta: PT.Raja Grafindo Persada. 
Robbins, S.P. (2012). Prinsip-Prinsip Perilaku Organisasi. Jakarta : Erlangga. Siagian, M. (2010). Manajemen Sumber Daya Manusia. Jakarta: Bumi Aksara. 